\title{
Estuarine circulation reversals and related rapid changes in winter near-bottom oxygen conditions in the Gulf of Finland, Baltic Sea
}

\author{
T. Liblik, J. Laanemets, U. Raudsepp, J. Elken, and I. Suhhova \\ Marine Systems Institute, Tallinn University of Technology, Akadeemia Road 15a, 12618 Tallinn, Estonia \\ Correspondence to: T. Liblik (taavi.liblik@msi.ttu.ee)
}

Received: 25 March 2013 - Published in Ocean Sci. Discuss.: 12 April 2013

Revised: 13 September 2013 - Accepted: 26 September 2013 - Published: 30 October 2013

\begin{abstract}
The reversal of estuarine circulation caused by southwesterly wind forcing may lead to vanishing of stratification and subsequently to oxygenation of deep layers during the winter in the Gulf of Finland. Six conductivity, temperature, depth (CTD)+oxygen transects (130 km long, 10 stations) were conducted along the thalweg from the western boundary to the central gulf (21 December 2011-8 May 2012). Two bottom-mounted ADCP were installed, one near the western border and the second in the central gulf. A CTD with a dissolved oxygen sensor was deployed close to the western ADCP. Periods of typical estuarine circulation were characterized by strong stratification, high salinity, hypoxic conditions and inflow to the gulf in the near-bottom layer. Two circulation reversals were observed: one in DecemberJanuary and one in February. The first reversal event was well developed; it caused the disappearance of the stratification and an increase in the oxygen concentration from hypoxic values to $270 \mu \mathrm{mol} \mathrm{L}^{-1}$ (to $6 \mathrm{~mL} \mathrm{~L}^{-1}$ ) throughout the water column along the thalweg and lasted approximately 1.5 months. Shifts from estuarine circulation to reversed circulation and vice versa were both associated with strong longitudinal (east-west) gulf currents (up to $40 \mathrm{~cm} \mathrm{~s}^{-1}$ ) in the deep layer. The change from oxygenated to hypoxic conditions in the western near-entrance area of the gulf occurred very rapidly, within less than a day, due to the intrusion of the hypoxic salt wedge from the NE Baltic Proper. In the eastern part of the gulf, good oxygen conditions caused by reversals remained for a few months.
\end{abstract}

\section{Introduction}

The bottom of the Baltic Sea is the largest dead zone in the world (Diaz and Rosenberg, 2008). Hypoxia (oxygen concentration of less than $90 \mu \mathrm{mol} \mathrm{L}^{-1}$ or $2 \mathrm{mLL}^{-1}$ ) has been present during the last $8000 \mathrm{yr}$ in the Baltic Sea (Zillén et al., 2008). The present extent of hypoxia in the Baltic Sea may be partly connected to the anthropogenic nutrient load and concurrent eutrophication (Conley et al., 2009). Eutrophication leads to increased sedimentation of organic material, thus increasing the area of anoxic bottoms and internal phosphorus loading. In addition, the hypoxic water volume displays a negative correlation with the total dissolved inorganic nitrogen pool: greater overall nitrogen removal with increased hypoxia (Vahtera et al., 2007). Hypoxia-related effects on the benthic ecosystem (e.g., Laine et al., 2007) and biogeochemical cycles of nutrients (e.g., Jäntti and Hietanen, 2012) are evident in the Gulf of Finland.

Deep layers of the Baltic Proper are supplied with oxygen only during the time of major inflows, when advecting highly saline, oxygen-rich water enters from the North Sea. Recently, such inflow events occurred in 1993 (Matthäus and Lass, 1995) and 2003 (Feistel et al., 2003). A significant ventilation of the Baltic Proper deep layers was observed after the major inflow in 1993, when the oxygen concentration in the Gotland deep rose to $90 \mu \mathrm{mol} \mathrm{L}-1\left(2 \mathrm{~mL} \mathrm{~L}^{-1}\right)$; however, the oxygen had disappeared by 1998 (Fonselius and Valderrama, 2003). The next ventilation event due to a major inflow occurred in 2003, when a near-bottom oxygen concentration of up to $180 \mu \mathrm{mol} \mathrm{L}{ }^{-1}\left(4 \mathrm{~mL} \mathrm{~L}^{-1}\right)$ was measured in the central Gotland Basin. Between the sporadic major inflows, stagnation periods have been observed, when a lack of deep advection decreased the near-bottom salinity 
and oxygen concentrations. During the period 1961-2005, the deep hypoxic zone extended on average across an area of approximately $50000 \mathrm{~km}^{2}$ in the Baltic Sea (Savchuk, 2010), despite temporary oxygenation during and after the major inflows. Higher oxygen concentrations have been observed in the intermediate depths $(80-120 \mathrm{~m})$ of the water column during periods of stagnation (Conley et al., 2002).

Because the deep water of the Gulf of Finland originates near the halocline of the Baltic Proper, a stronger and shallower halocline in the Baltic Proper induces stronger stratification and increased hypoxia in the Gulf of Finland; the opposite change takes place when the halocline is weaker and deeper (Conley et al., 2009). It has been demonstrated that the halocline was stronger (Liblik and Lips, 2011) and oxygen depletion increased (Laine et al., 2007) in the Gulf of Finland after the major inflows of North Sea waters in 1993 and 2003.

Elken et al. (2003) concluded, based on summer CTD measurements, that halocline weakening that cannot be explained by vertical mixing alone may occur in the gulf. They suggested that southwesterly (generally up-estuary) wind forcing caused the reversal of estuarine circulation in the gulf: the surface-layer flows into the estuary, and the deep layer flows out (i.e., the opposite of normal estuarine circulation). In contrast, northeasterly and northerly winds support standard estuarine circulation, resulting in stronger stratification (Elken et al., 2003; Liblik and Lips, 2011) and import of phosphorus-rich waters from the deeper sub-halocline layers of the Baltic Proper (Lips et al., 2008). Elken et al. (2013) analyzed routine CTD measurements and wind data over several decades to investigate possible changes in the frequency of wintertime stratification collapse events. They found that the bottom-to-surface density difference becomes close to zero (note that the winter is already characterized by the weakest stratification in the Gulf, see Haapala and Alenius, 1994) during wind-induced strong estuarine circulation reversal events caused by up-estuary (southwesterly) wind forcing. They also found that since the 1990s, the frequency and duration of such stratification collapse events have increased due to the shift in the wind regime (i.e., the considerable increase in the west-southwesterly wind impulse in December-January). It is commonly understood that mixing of the entire water column will improve the near-bottom oxygen conditions either (1) by direct vertical stirring processes only or (2) by stirring in combination with wind-induced straining (differential lateral advection), with the latter factor dominating. These two types of mixing may result in various rates of change in the near-bottom salinity and oxygen content, perhaps also resulting in various release rates of phosphorus from the sediments (e.g., Viktorsson et al., 2012), but these rates of change remained unknown because of a lack of purposeful observations.

The primary aim of the present study was to observe and map details of winter stratification changes in the Gulf of Finland (as a model for the larger non-tidal estuary) to identify the conditions under which the stratification collapse events occur. Specific goals were to determine whether these events are caused primarily by estuarine circulation reversals or if the vertical stirring dominates and to estimate the effect of these events on the spatiotemporal variability of the oxygen concentration in the deep layer of the gulf. When planning these studies, we hypothesized that a reversal of the estuarine circulation and concurrent disappearance of the salt wedge may rapidly and remarkably alter the oxygen conditions in the deep layer of the Gulf of Finland.

Following a description of the study area and the methods used, this paper presents an analysis of (1) a regular time series of wind conditions, (2) repeated transects of CTD and $\mathrm{O}_{2}$ along the thalweg, and (3) time-series observations at two deep mooring locations: ADCP (acoustic Doppler current profiler) recording of current profiles and near-bottom point-recording of CTD and $\mathrm{O}_{2}$. The presentation and analysis of observational results is followed by discussion and conclusions.

\section{Study area, data and methods}

\subsection{Study area and surveys}

The Gulf of Finland lies in the northeastern part of the Baltic Sea (Fig. 1). Due to the near isolation of the Baltic Sea from the ocean, tidal oscillations of the sea level are of minor importance in the dynamics of the gulf (e.g., Kullenberg, 1981), which is unique among the world's estuaries (Hansen and Rattray, 1966; MacCready and Geyer, 2010). The gulf is approximately $400 \mathrm{~km}$ long and varies from 48 to $135 \mathrm{~km}$ wide. The maximum depths exceed $100 \mathrm{~m}$ in the central and western areas. River discharge is concentrated in the eastern part of the gulf, where the inflow from the Neva River averages $77.6 \mathrm{~km}^{3} \mathrm{yr}^{-1}$, which constitutes approximately two thirds of the freshwater inflow to the gulf (Bergström and Carlsson, 1994). As a result, the surface-layer salinity varies from approximately $1 \mathrm{~g} \mathrm{~kg}^{-1}$ in the easternmost area up to $6-7 \mathrm{~g} \mathrm{~kg}^{-1}$ at the entrance (e.g., Haapala and Alenius, 1994). The deep layer is characterized by a slight westward salinity increase (e.g., Liblik and Lips, 2011). The seasonal thermocline forms at the beginning of May, develops during the summer and starts to erode by the end of August (e.g., Alenius et al., 1998). The thermocline is usually situated at a depth of 10-15 $\mathrm{m}$ and is strongest in July-August, when the surface-layer temperature rises to an average of $17^{\circ} \mathrm{C}$ in the open gulf (Liblik and Lips, 2011). During the winter, the water masses are rather well mixed down to a depth of $60 \mathrm{~m}$ (Haapala and Alenius, 1994; Alenius et al., 2003). The gulf has a free connection to the NE Baltic Proper; a sill is lacking, and the salinity may therefore increase below the halocline (located at a depth of 60-70 m, Alenius et al., 1998) in the western part of gulf to as much as $10 \mathrm{~g} \mathrm{~kg}^{-1}$, (i.e., values typical of the open sea). Greater sea depths and steeper 


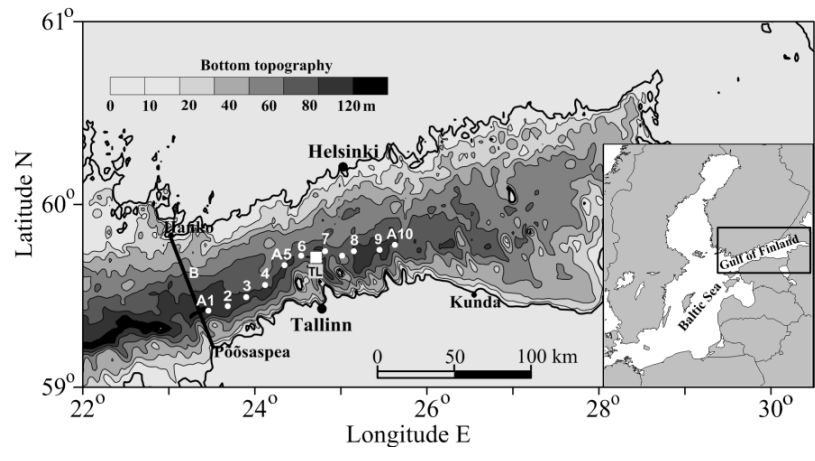

Fig. 1. Map of the study area in the Gulf of Finland. The solid white circles represent the locations of the CTD stations (A1-A10) along the thalweg of the gulf. The two bottom-mounted ADCPs were located at CTD stations A3 and A9. The bottom-mounted ADCP at location A3 was equipped with a CTD and dissolved oxygen sensor. The solid white square represents the location of the wind measurements at Tallinnamadal Lighthouse (TL). The bottom topography is drawn from the gridded topography in meters (Seifert et al., 2001). The western border of the gulf is defined as a line between the peninsulas of Põõsaspea and Hanko (line B).

bottom slopes are present along the southern coast (Fig. 1). The line connecting the greatest depths in cross sections (i.e., the thalweg) is located closer to the southern coast. A slight (less than $10 \mathrm{~m}$ ) cross-gulf bottom rise between Tallinn and Helsinki separates the two (western and central) deeper basins.

We performed six surveys along the thalweg of the gulf during the winter of 2011-2012 and the spring of 2012 onboard the R/V Salme, which belongs to the Marine Systems Institute at Tallinn University of Technology. Specifically, these six surveys were performed on 21 December (2011), 24-25 January, 7-8 February, 29 February, 15-16 March and 8 May (2012). The ten sampling stations, designated A1 through A10, were located in the western and central parts of the gulf (Fig. 1). The westernmost station, A1, was located near the western end of the gulf, and station A10 was located approximately $130 \mathrm{~km}$ east of station A1, exceeding the bottom elevation near Tallinn-Helsinki. The distances between the stations varied within a range of $10-17 \mathrm{~km}$.

At all of the stations, vertical profiles of the temperature, salinity and dissolved oxygen were recorded, using a SeaBird SBE 19Plus V2 CTD SEACAT profiler equipped with the dissolved oxygen sensor SBE43. No dissolved oxygen profiles were recorded on 8 May; only the bottom oxygen concentrations were acquired during that cruise. The quality of the salinity data was checked against the water sample analyses using a high-precision salinometer, the 8410A Portasal (Guildline). The Sea-Bird SBE 19Plus CTD profiler overestimated the salinity by an average of $0.041 \mathrm{~g} \mathrm{~kg}^{-1}$. The dissolved oxygen sensor was calibrated against water sample analyses. The dissolved oxygen concentration in bottle samples was measured using the OX 4000 L meters (WWR
International, LLC). In all, 60 data pairs were used to find the best linear fit between the dissolved oxygen (DO) values obtained using the SBE43 and those obtained from the sample analyses. That linear fit is given by the equation $\mathrm{DO}=\mathrm{DO}_{\mathrm{SBE}} \times 1.41\left(r^{2}=0.99\right)$, where $\mathrm{DO}_{\mathrm{SBE}}$ is the dissolved oxygen recorded using SBE43 sensor. The accuracy of SBE43 is $2 \%$ of saturation. The OX $4000 \mathrm{~L}$ meter has accuracy of $0.5 \%$ of the measured value within the temperature range +5 to $+30^{\circ} \mathrm{C}$. Measurements for lower temperatures can be less precise.

\subsubsection{Autonomous recording}

We installed two buoy stations with acoustic Doppler current profilers (ADCP, $300 \mathrm{kHz}$; Teledyne RD Instruments) on the seafloor at the locations of stations A3 and A9; the seafloor at those locations was at depths of $91 \mathrm{~m}$ and $87 \mathrm{~m}$, respectively. These current profilers were set to collect measurements in 40 and 38 vertical bins, respectively, in $2 \mathrm{~m}$ depth increments. The shallowest bin was at a depth range of $7-$ $9 \mathrm{~m}$, and the deepest was at a range of $85-87 \mathrm{~m}$ and $81-83 \mathrm{~m}$. A Seabird SBE 16Plus V2 CTD SEACAT conductivity and temperature recorder with the SBE43 dissolved oxygen sensor was also deployed at station A3. The recorder was set at a depth of $86 \mathrm{~m}$ ( $5 \mathrm{~m}$ above the seafloor). The current profilers were set to take measurements at intervals of $30 \mathrm{~min}$, and the SBE 16 recorded data at $1 \mathrm{~h}$ intervals. The dissolved oxygen sensor was calibrated against the results of the water sample analyses $\left(r^{2}=0.99\right)$.

\subsubsection{Wind and sea level data, NAO index}

The wind data were obtained near the thalweg at Tallinnamadal Lighthouse (Fig. 1). The wind speed and direction were measured at an elevation of $36 \mathrm{~m}$ above the sea surface and were reported as hourly averages. The wind speed was multiplied by a height correction coefficient of 0.91 (Launiainen and Saarinen, 1984) to reduce the recorded wind speed to that of the reference height of $10 \mathrm{~m}$ during neutral atmospheric stratification. In addition, we used the wind data time series (1981-2012) from the Kalbådagrund weather station (Finnish Meteorological Institute), because the time series at Tallinnamadal was too short for certain analyses. The wind speed and direction data from Kalbådagrund was available every third hour as a $10 \mathrm{~min}$ average. Keevallik and Soomere (2010) found slight differences, both in wind direction and speed, between Tallinnamadal and Kalbådagrund. In the present study, we used the data from the Tallinnamadal station as the primary descriptor of the wind characteristics in the western gulf during the study period. The wind velocity components were calculated along the axis from SSW to NNE, with positive values corresponding to NNE. The winds from the SSW are most favorable for estuarine circulation reversal, and those from the NNE the most favorable for estuarine circulation (Liblik and Lips, 2011). 
Hourly sea level data were obtained from the Kunda coastal station (Estonian Hydrological and Meteorological Institute), located on the southern coast of the Gulf of Finland. The sea level values in Estonia are relative to the longterm mean $(0 \mathrm{~cm})$.

The NAO index (Jones et al., 1997) data (http://www.cru. uea.ac.uk/ timo/datapages/naoi.htm) were used to characterize the airflow during the study period and compare it with the long-term data.

\subsection{Calculation procedures}

The acquired salinity data expressed as values on the practical salinity scale (Fofonoff and Millard Jr., 1983) were multiplied by 1.0047 (Millero et al., 2008) and presented as values of absolute salinity $\left(\mathrm{g} \mathrm{kg}^{-1}\right)$.

The ADCP velocity, sea level and wind data were filtered using a $36 \mathrm{~h}$ cutoff Butterworth filter (Butterworth, 1930).

The areas and volumes of hypoxic near-bottom waters (oxygen concentration $\leq 90 \mu \mathrm{mol} \mathrm{L}{ }^{-1}$ ) were estimated from the $\mathrm{O}_{2}$ profiles taken on the transect located along the thalweg, assuming that cross-transect changes are small. Using the gridded topography by Seifert et al. (2001), the observed upper boundaries of the hypoxic layer were extrapolated across the transect and interpolated along the transect. The area of sea used in the numerical integration was bounded by the western border of the Gulf of Finland and the easternmost station, A10. This region has a surface area of approximately $10000 \mathrm{~km}^{2}$ and volume of approximately $450 \mathrm{~km}^{3}$. In a similar manner we also calculated the bottom area and volume of the water with a salinity of $\geq 9.3 \mathrm{~g} \mathrm{~kg}^{-1}$.

\section{Results}

\subsection{Wind conditions}

Prior to the start of our observation campaign on 21 December 2011, weak to moderate winds from various directions blew during the first 20 days of November (Fig. 2). From the last 10 days of November until the end of December, the wind conditions in the study area were shaped by strong air flow from south and southwest, reaching a maximum wind speed of $25 \mathrm{~m} \mathrm{~s}^{-1}$ on 26 December. Variable and weaker winds prevailed during the first half of January. The second half of January was shaped by a high atmospheric pressure system, resulting in low air temperatures and calm wind conditions. Southeasterly and southwesterly winds prevailed in February, and southwesterly winds prevailed in March. However, the prevailing winds in February-March were frequently interrupted by northerly winds or calm periods. Only in mid-February was there a long period of continuous southeasterly and southwesterly winds. As is typical of the spring, variable and weaker winds were observed from April until the end of the study period.
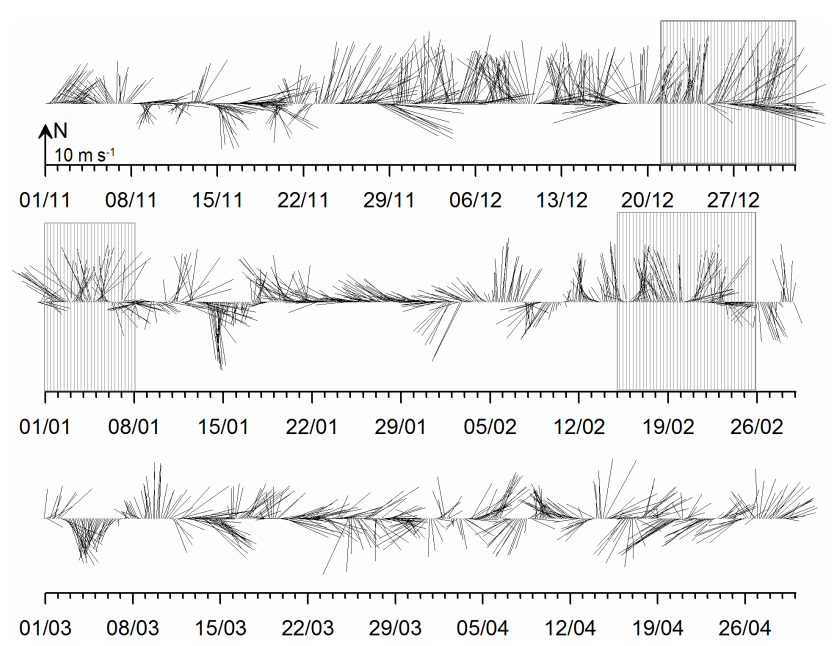

Fig. 2. Time series of the $10 \mathrm{~m}$ level Tallinnamadal wind vector from 1 November 2011 to 30 April 2012. Shaded areas mark time intervals when estuarine circulation reversals prevailed.

\subsection{CTD and $\mathrm{O}_{2}$ transects along the thalweg}

A weakly stratified water column was observed on 21 December (Fig. 3). The density difference between the nearbottom and surface water did not exceed $0.7 \mathrm{~kg} \mathrm{~m}^{-3}$ along the thalweg. At stations A2-A7, the density difference was $0.3 \mathrm{~kg} \mathrm{~m}^{-3}$ or less. The salinity along the entire section was relatively low: it exceeded $7.0 \mathrm{~g} \mathrm{~kg}^{-1}$ only in the near-bottom layer at the westernmost station, A1, and at stations A8-A10. The east-west salinity gradient in the surface layer was relatively weak, and the salinity varied from $6.2-6.3 \mathrm{~g} \mathrm{~kg}^{-1}$ in the easternmost part to $6.4-6.5 \mathrm{~g} \mathrm{~kg}^{-1}$ in the westernmost part. The temperature clearly exceeded the maximum density temperature in the entire section and varied in the range of $5.8-7.1{ }^{\circ} \mathrm{C}$. The water column in the entire section was well oxygenated, and even near the seafloor the oxygen concentration at all stations exceeded $220 \mu \mathrm{mol} \mathrm{L}^{-1}\left(5 \mathrm{~mL} \mathrm{~L}^{-1}\right)$.

On 24-25 January, a well-defined deep saltwater wedge was observed at stations A1-A6, separated from the upper mixed layer by a strong halocline. The salinity above the halocline varied in the range of $6.4-6.8 \mathrm{~g} \mathrm{~kg}^{-1}$, while salinity up to $9.9 \mathrm{~g} \mathrm{~kg}^{-1}$ was observed in the deep layer. This halocline was relatively sharp: for example, a salinity increase from 6.8 to $9.8 \mathrm{~g} \mathrm{~kg}^{-1}$ was observed between depths of 75 and $76.5 \mathrm{~m}$ at station $\mathrm{A} 4$. The vertical salinity distribution at the eastern stations (A7-A10) was clearly more uniform. The temperature varied in the range of $3.1-6.0^{\circ} \mathrm{C}$, increasing with depth and decreasing eastward. The oxygen conditions in the section were strongly related to the extent of the salt wedge. The water column above the salt wedge was well oxygenated: the oxygen concentrations were $>360 \mu \mathrm{mol} \mathrm{L}^{-1}$ $\left(8 \mathrm{~mL} \mathrm{~L}^{-1}\right)$. As a result of the salt water intrusion, the bottom water was hypoxic at stations $\mathrm{A} 1-\mathrm{A} 6$, while the water was nearly fully saturated with oxygen at stations A7-A10. 

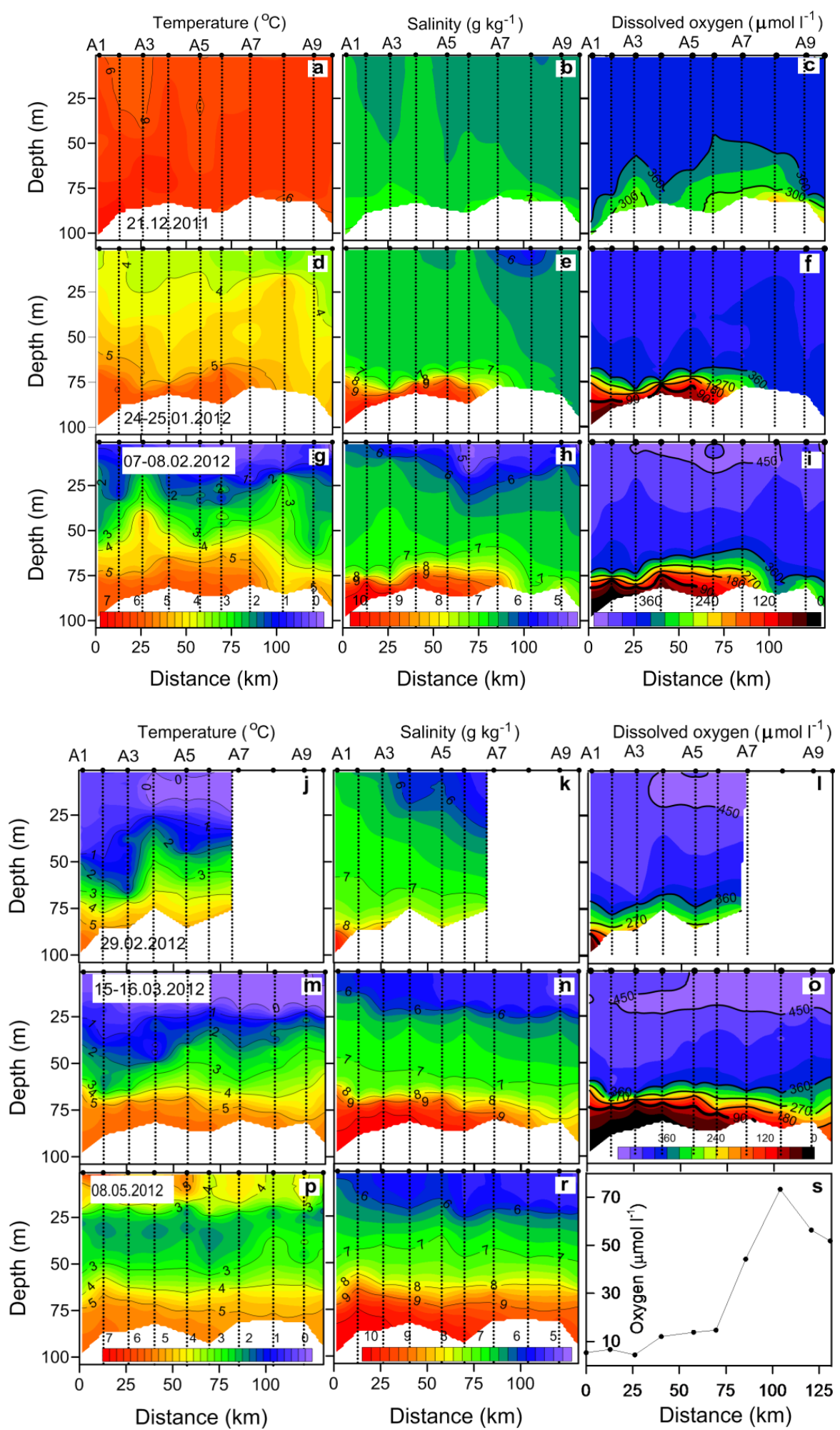

Fig. 3. Vertical sections of temperature (interval $0.25^{\circ} \mathrm{C}$ ), salinity (interval $0.25 \mathrm{~g} \mathrm{~kg}^{-1}$ ) and dissolved oxygen (interval $30 \mu \mathrm{mol} \mathrm{L}-1$ ) on 21 December 2011 (a, b, c), 24-25 January 2012 (d, e, f), 7-8 February (g, h, i), 29 February (j, k, l), 15-16 March (m, n, o) and 8 May (p, r) measured along the thalweg of the gulf. A thick contour line marks the dissolved oxygen concentration of $90 \mu \mathrm{mol} \mathrm{L}{ }^{-1}$. On $8 \mathrm{May}$, only near-bottom layer dissolved oxygen concentrations were available (s). Values on the $x$ axis indicate distance from the westernmost station (see Fig. 1). 
Consequently, the near-bottom oxygen levels were higher even at the easternmost stations compared to levels recorded during the previous survey.

Two weeks later, by 7-8 February, the deep saltwater wedge was observed approximately $15 \mathrm{~km}$ east of its former position. A slight increase in salinity was also observed at the three easternmost stations. The development of a nearsurface halocline was observed in the upper part of the water column at a depth of $10-20 \mathrm{~m}$ at all of the stations. The surface-layer water temperature varied in the range of $-0.2-$ $0.8^{\circ} \mathrm{C}$. Its salinity was in the range of $4.7-5.5 \mathrm{~g} \mathrm{~kg}^{-1}$ at stations $\mathrm{A} 3-\mathrm{A} 10$, while the temperature and salinity were 0.8 $0.9^{\circ} \mathrm{C}$ and $6.0 \mathrm{~g} \mathrm{~kg}^{-1}$, at the two westernmost stations. The oxygen content of the near-bottom layer was slightly depressed along the entire section, but the oxygen concentrations still exceeded $270 \mu \mathrm{mol} \mathrm{L}^{-1}\left(6 \mathrm{~mL} \mathrm{~L}^{-1}\right)$ throughout the water column in the eastern part of the study area.

On 29 February, the section was not fully surveyed, due to heavy ice conditions. The available data from the western part of the section indicated westward movement of a deep layer salt wedge. The halocline was still evident at the westernmost station, A1, where the salinity exceeded $9 \mathrm{~g} \mathrm{~kg}^{-1}$. The density difference between the bottom and surface water exceeded $1 \mathrm{~kg} \mathrm{~m}^{-3}$ at all of the stations where measurements were taken. Similar to conditions in the deeper layer, the near-surface halocline had weakened and was absent from the upper part of the water column at certain stations. The surface-layer salinity still exhibited a strong decrease toward the east, decreasing from $6.8 \mathrm{~g} \mathrm{~kg}^{-1}$ at station A1 to $5.2 \mathrm{~g} \mathrm{~kg}^{-1}$ at station A7. The surface-layer temperature was below $0{ }^{\circ} \mathrm{C}$ at stations $\mathrm{A} 4-\mathrm{A} 7$, while it was slightly over $0{ }^{\circ} \mathrm{C}$ at the westernmost stations, A1-A3. With the exception of the near-bottom layer at station A1, the oxygen concentration exceeded $90 \mu \mathrm{mol} \mathrm{L}^{-1}$ at all of the stations.

By 15-16 March, both of the haloclines had reformed. The saltwater wedge in the deep layer and the fresher water in the upper layer were evident at all of the stations. The salinity decreased eastward from 5.8 (station A1) to $5.0 \mathrm{~g} \mathrm{~kg}^{-1}$ (station A10) in the upper layer and from 10.2 to $8.4 \mathrm{~g} \mathrm{~kg}^{-1}$ in the near-bottom layer, respectively, at those two stations. The temperature increased from $0{ }^{\circ} \mathrm{C}$ near the surface to $5.5^{\circ} \mathrm{C}$ in the near-bottom layer. The reappearance of the hypoxic salt wedge affected the deep water oxygen content across the entire section. However, at the easternmost stations, A8-A10, the water in the bottom layer still contained oxygen at a concentration over $90 \mu \mathrm{mol} \mathrm{L}^{-1}$. Compared to the situation on 7-8 February, the hypoxic water layer above the bottom was thicker. In the western half of the section, the oxygen concentration had decreased below $90 \mu \mathrm{molL}^{-1}$ below a depth of 71-74 m.

The water with oxygen saturation up to $107 \%$ was observed on 7-8 February, 29 February and 15-16 March in the upper layer where temperature was $\leq 0^{\circ} \mathrm{C}$. The observed high saturation was likely caused by the growth of phytoplankton. Chlorophyll $a$ fluorescence (data not shown) was also higher in the same layer. High fluorescence values were not observed throughout the whole water column in previous cruises.

The last survey along the thalweg was conducted at the end of the study period, on 8 May. The upper layer temperature has increased to $4-5^{\circ} \mathrm{C}$. The cold intermediate layer was positioned between depths of 20 and $50 \mathrm{~m}$. In comparison to the previous survey, the salinity in the upper $35 \mathrm{~m}$ layer exhibited minor changes. The upper layer halocline was positioned at a depth of $25 \mathrm{~m}$. The deep layer of saline water had extended across the entire section, such that the deep water halocline was observed between depths of 65 and $75 \mathrm{~m}$. The isohaline of $7 \mathrm{~g} \mathrm{~kg}^{-1}$ had risen from a depth of $50-60 \mathrm{~m}$ to $40-50 \mathrm{~m}$ depth between the two surveys, which indicates the eastward transport of the lower layer water. The density difference between the surface and bottom layers exceeded $3 \mathrm{~kg} \mathrm{~m}^{-3}$ at all of the stations. The oxygen distribution was consistent with a deep water salinity distribution, and the near-bottom water was hypoxic at all of the stations. Nevertheless, a slight eastward increase in oxygen, from 4$9 \mu \mathrm{mol} \mathrm{L}^{-1}\left(0.1-0.2 \mathrm{mLL}^{-1}\right)$ at the three westernmost stations to $54-71 \mu \mathrm{mol} \mathrm{L}-1 \quad\left(1.2-1.6 \mathrm{~mL} \mathrm{~L}^{-1}\right)$ at the three easternmost stations, was still evident.

\subsection{Time series of current profiles, temperature, salinity and oxygen}

At both of the current measurement sites, the currents were variable and occasionally very strong (Figs. 4 and 5). The average current speeds in the eastern part of study area (station A9) varied from $7.5 \mathrm{~cm} \mathrm{~s}^{-1}$ at an $82 \mathrm{~m}$ depth (deepest measured bin) to $11.6 \mathrm{~cm} \mathrm{~s}^{-1}$ at an $8 \mathrm{~m} \mathrm{depth} \mathrm{(shallowest}$ measured bin), while the maximum recorded speeds were in the range of $40-56 \mathrm{~cm} \mathrm{~s}^{-1}$ in the upper $30 \mathrm{~m}$ and $33-$ $40 \mathrm{~cm} \mathrm{~s}^{-1}$ below that depth. At station A3, the average current speed was stronger in the deep layer and upper layer (11$13 \mathrm{~cm} \mathrm{~s}^{-1}$ ) and slightly weaker in the intermediate layer (9$\left.11 \mathrm{~cm} \mathrm{~s}^{-1}\right)$. The highest recorded speeds were in the range of $35-49 \mathrm{~cm} \mathrm{~s}^{-1}$ at a depth of $26-86 \mathrm{~m}$, while the speeds exceeded $52 \mathrm{~cm} \mathrm{~s}^{-1}$ in the upper part $(8-26 \mathrm{~m})$ of the water column. The strongest current, $88 \mathrm{~cm} \mathrm{~s}^{-1}$, was recorded at a depth of $12 \mathrm{~m}$ during a southwesterly storm event on 26 December.

The temporal progression of cumulative wind stress indicated that reversal-favorable winds (from the SSW) started on 25 November and lasted until 5 January (Fig. 6). The cumulative wind stress was approximately $11 \mathrm{~N} \mathrm{~m}^{-2} \mathrm{~d}$ during that period. At the onset of winds, the sea level at Kunda rose from $-10 \mathrm{~cm}$ to $66 \mathrm{~cm}$ (36h low-pass filtered). The last 18 days of flow reversal (21 December to 8 January) were covered by measurements. The vertical flow structures at both measurement sites were dominated by barotropic outflow opposite to the wind direction from the last 10 days of December through the first half of January (Figs. 4 and 5): during the period of weak haline stratification 
(Fig. 3b). During the reversal period beginning on 21 December, the temperature, salinity and dissolved oxygen concentration varied in a relatively narrow range: $5.0-6.6^{\circ} \mathrm{C}, 6.5-$ $6.8 \mathrm{~g} \mathrm{~kg}^{-1}$ and $326-380 \mu \mathrm{mol} \mathrm{L}^{-1}\left(7.3-8.5 \mathrm{~mL} \mathrm{~L}^{-1}\right)$, respectively. A temperature decrease was evident throughout this period, however, and shorter-period fluctuations with simultaneous changes in salinity were observed: a temperature increase of $0.5^{\circ} \mathrm{C}$ was accompanied by a salinity increase of approximately $0.1 \mathrm{~g} \mathrm{~kg}^{-1}$.

Beginning on 8 January, short-term variations in the wind direction from the south to the northeast were well reflected in the deep layer current, in which the earlier prevailing outflow was temporary replaced by inflow. This period of a variable flow regime ended on 14 January with the help of 1.5 days of a northerly wind impulse and a subsequent period of weaker winds (Fig. 2). The re-establishment of estuarine circulation caused a deep salt wedge intrusion extending to station A3 (Fig. 3e) and an interruption of barotropic flow (Fig. 4). However, the haline stratification and current shear at station A9 (Fig. 5) still remained weak. Inflow prevailed throughout the water column until mid-February and was particularly strong in the deep layer. The re-establishment of estuarine circulation coincided closely with the drop in the sea level in the gulf. In the near-bottom layer, the dissolved oxygen levels during the period of estuarine circulation rarely exceeded $45 \mu \mathrm{mol} \mathrm{L}-1\left(1 \mathrm{mLL}^{-1}\right)$, while the salinity varied in a range of $9.4-10.3 \mathrm{~g} \mathrm{~kg}^{-1}$ (Fig. 6). In contrast with the previous period, the increases in salinity were accompanied by slight decreases in temperature.

The second reversal event was induced by southerly winds beginning in mid-February and peaked after southerly winds prevailed for 12 days; the cumulative wind stress during that period was $2 \mathrm{~N} \mathrm{~m}^{-2} \mathrm{~d}$. The reversal-favorable winds raised the sea level and altered the estuarine flow in the deep layer. Strong outflow in the deep layer that extended to a $30-40 \mathrm{~m}$ depth and simultaneous inflow in the upper layer were observed in the second half of February at station A3, located near the west end of the section (Fig. 4). This event was also evident at station A9, near the east end of the section (Fig. 5), where inflow prevailed in the upper $20 \mathrm{~m}$ and outflow prevailed in the rest of the water column. Compared to the strong near-bottom outflow at location A3, the outflow was at a maximum in the middle of the water column and was much weaker at location A9. The second reversal event was not as strong as the one observed in December-January. This reversal event peaked with a dissolved oxygen concentration of $210 \mu \mathrm{mol} \mathrm{L}^{-1}\left(4.7 \mathrm{~mL} \mathrm{~L}^{-1}\right)$, while the salinity simultaneously decreased to $8.2 \mathrm{~g} \mathrm{~kg}^{-1}$. The dissolved oxygen concentration and salinity fluctuated in a relatively wide range during this event and correlated strongly.

As a consequence of a short-duration wind impulse from the north at the beginning of March, inflow reappeared in the deep layer, the sea level dropped and the salt wedge was reestablished simultaneously at the buoy station on 3 March. The flow structure at location A3 was multi-layered, with

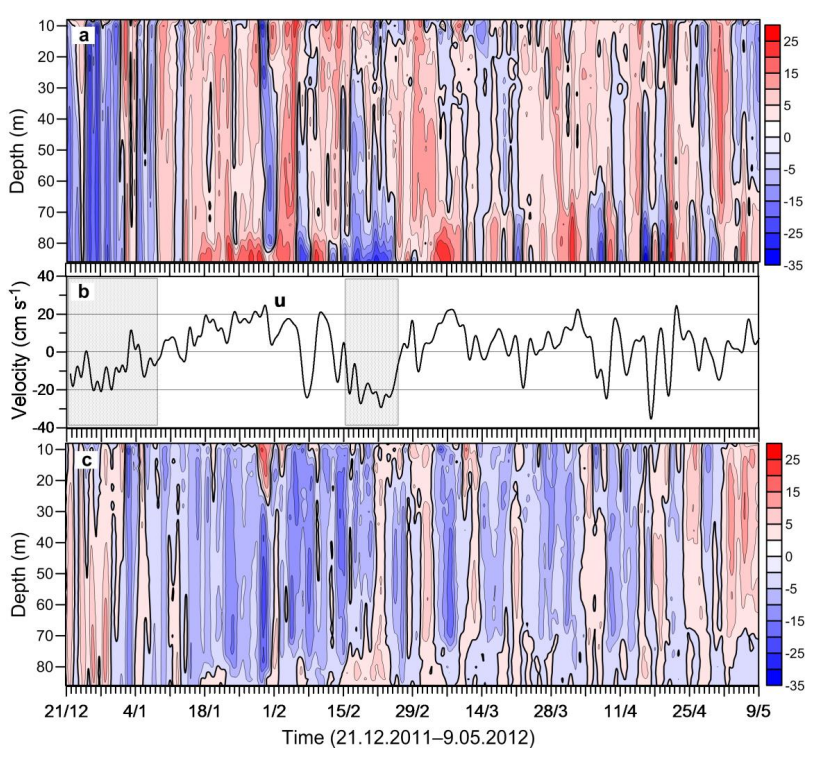

Fig. 4. (a) Temporal progression of vertical distribution of lowpass filtered along-gulf axis current velocity component $(u)$ and (c) cross-gulf axis current velocity component $(v)$ in $\mathrm{cm} \mathrm{s}^{-1}$ at the location of mooring station A3 from 21 December 2011 to 9 May 2012. Positive velocities (red) denote the inflow into the gulf or northward flow, and negative velocities (blue) denote the opposite, respectively. (b) Temporal course of along-gulf axis current velocity component $(u)$ at the depth of $85 \mathrm{~m}$. Shaded areas mark time intervals when estuarine circulation reversals were observed at location A3.

the strongest current shear in the deep halocline. The mean flow, however, was to the east over the entire water column. Although we observed short periods of outflow in the deep layer and simultaneous slight decreases and increases in the salinity and oxygen concentration, respectively; the oxygen concentration remained below $45 \mu \mathrm{mol} \mathrm{L}^{-1}\left(1 \mathrm{mLL}^{-1}\right)$ until the end of the study period on 8 May. At the same time that the flow was weaker but more persistent at station A9, outflow prevailed in the upper layer and inflow in the deep layer, which, on average, resulted in typical estuarine flow in the eastern part of study area.

\subsection{Effects of reversal events on oxygen conditions in the gulf}

A hypoxic near-bottom salt wedge, originating in the NE Baltic Proper, penetrated the gulf in the middle of January after a reversal event that had lasted since the end of November. The salt wedge had reached station A6 by 24-25 January, and a similar situation was observed on 7-8 February. On 29 February, during a weaker reversal event, hypoxic water was present only at the westernmost station. It reappeared at station A3 on 3 March. By 15-16 March, the salty and hypoxic water reappeared along the thalweg at stations A1-A7, while the near-bottom oxygen concentration still exceeded 


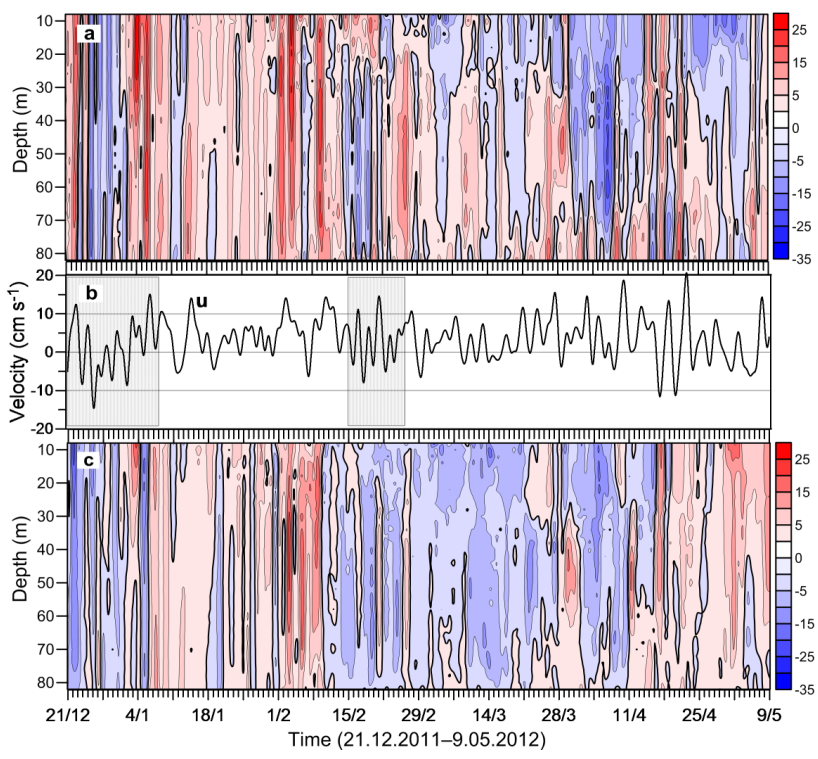

Fig. 5. (a) Temporal course of the vertical distribution of lowpass filtered along-gulf axis current velocity component $(u)$ and (c) cross-gulf axis current velocity component $(v)$ in $\mathrm{cm} \mathrm{s}^{-1}$ at the location of mooring station A9 from 21 December 2011 to 9 May 2012. Positive velocities (red) denote the inflow into the gulf or northward flow, and negative velocities (blue) denote the opposite, respectively. (b) Temporal course of along-gulf axis current velocity component $(u)$ at a depth of $85 \mathrm{~m}$. Shaded areas mark time intervals when estuarine circulation reversals prevailed.

$90 \mu \mathrm{mol} \mathrm{L}^{-1}$ at the three easternmost stations. The thickness of the hypoxic water column had increased compared to the situation during previous cruises. On 8 May, hypoxic water was present at all of the stations, but the oxygen concentrations were still slightly higher in the eastern part of the study area than in the western part.

The oxygen concentrations within and below the halocline were strongly related to the salinity: the estimated areas and volumes occupied by hypoxic water and water with a salinity $\geq 9.3 \mathrm{~g} \mathrm{~kg}^{-1}$ showed correlations with values of $r^{2}=0.99$ and $r^{2}=0.98$, respectively $(n=5 ; p<0.01)$. The estimated bottom area covered by hypoxic water (Table 1 ) was $>1300 \mathrm{~km}^{2}$ on $15-16$ March (the case of normal estuarine circulation), whereas the area was nearly hypoxic-free even during the relatively weak reversal event in February. The hypoxic area and volume were even greater after the spring bloom on 8 May.

\section{Discussion}

The surveying along the thalweg and the time-series observations of the near-bottom layer revealed high variability in the thermohaline structure and oxygen concentration in the Gulf of Finland. We found that the vertical flow structure, particularly the bottom current, is the most important fac-
Table 1. Estimated hypoxic bottom areas and hypoxic water volumes. On 8 May hypoxic values were calculated on the basis of bottom oxygen concentrations and salinity profiles: linear regression between sea areas and volumes occupied by hypoxic water and by water with salinity $\geq 9.3 \mathrm{~g} \mathrm{~kg}^{-1}$ was used in estimation. Area under consideration (approximately $10000 \mathrm{~km}^{2}$ ) was between the western border of the Gulf of Finland and the easternmost station, A10 (Fig. 1).

\begin{tabular}{lll}
\hline Cruise & $\begin{array}{l}\text { Hypoxic area } \\
\left(\mathrm{km}^{2}\right)\end{array}$ & $\begin{array}{l}\text { Hypoxic water } \\
\text { volume }\left(\mathrm{km}^{3}\right)\end{array}$ \\
\hline 21 Dec & 0 & 0 \\
24-25 Jan & 510 & 2.6 \\
7-8 Feb & 770 & 4.9 \\
29 Feb & 130 & 0.8 \\
15-16 Mar & 1380 & 12.0 \\
8 May & 1650 & 14.6 \\
\hline
\end{tabular}

tor shaping the deep water characteristics in the winter: the oxygen conditions in the bottom layer of the gulf can be explained by spatiotemporal variability of the salt wedge. We observed two estuarine circulation reversal events with durations of 1.5 and 0.5 months, in December-January and February, respectively. As a consequence, the stratification was greatly weakened, the current structure was altered and the hypoxic salt wedge disappeared during those events. Our observations revealed that differential advection in case of temporary estuarine reversal (anti-estuarine straining) is an important factor for the stratification disappearance, as suggested earlier by Elken et al. (2003) and Elken et al. (2013). Unfortunately, within the present study it was not possible to establish the balance of different advection and diffusion terms during rapid changes of stratification because of the long time interval between the along-thalweg mappings and missing information on transverse flow and density structures.

These halocline disappearance and reappearance events coincided with the presence of strong near-bottom currents. The re-establishment of a deep layer salt wedge may occur very rapidly, within $12 \mathrm{~h}$. The reactivations of estuarine circulation were associated with a strong inflow and reversal event in February that began with strong outflow in the deep layer. However, when the reversal drastically weakened the stratification (as in December-January) upwind barotropic flow along the thalweg was also observed, and the current shear maximum disappeared together with the halocline. The current structure in the deep layer of the gulf has not been rigorously studied, but strong near-bottom currents appear to be a common feature of the gulf (Almroth et al., 2009; Lagemaa et al., 2010; Liblik and Lips, 2012). Strong wind-induced currents in the deep layer have also been observed in other estuaries, such as in the Long Island Sound (Whitney and Codiga, 2011). The observed upwind barotropic flow along the thalweg allowed for us to assume a temporary wind-induced 


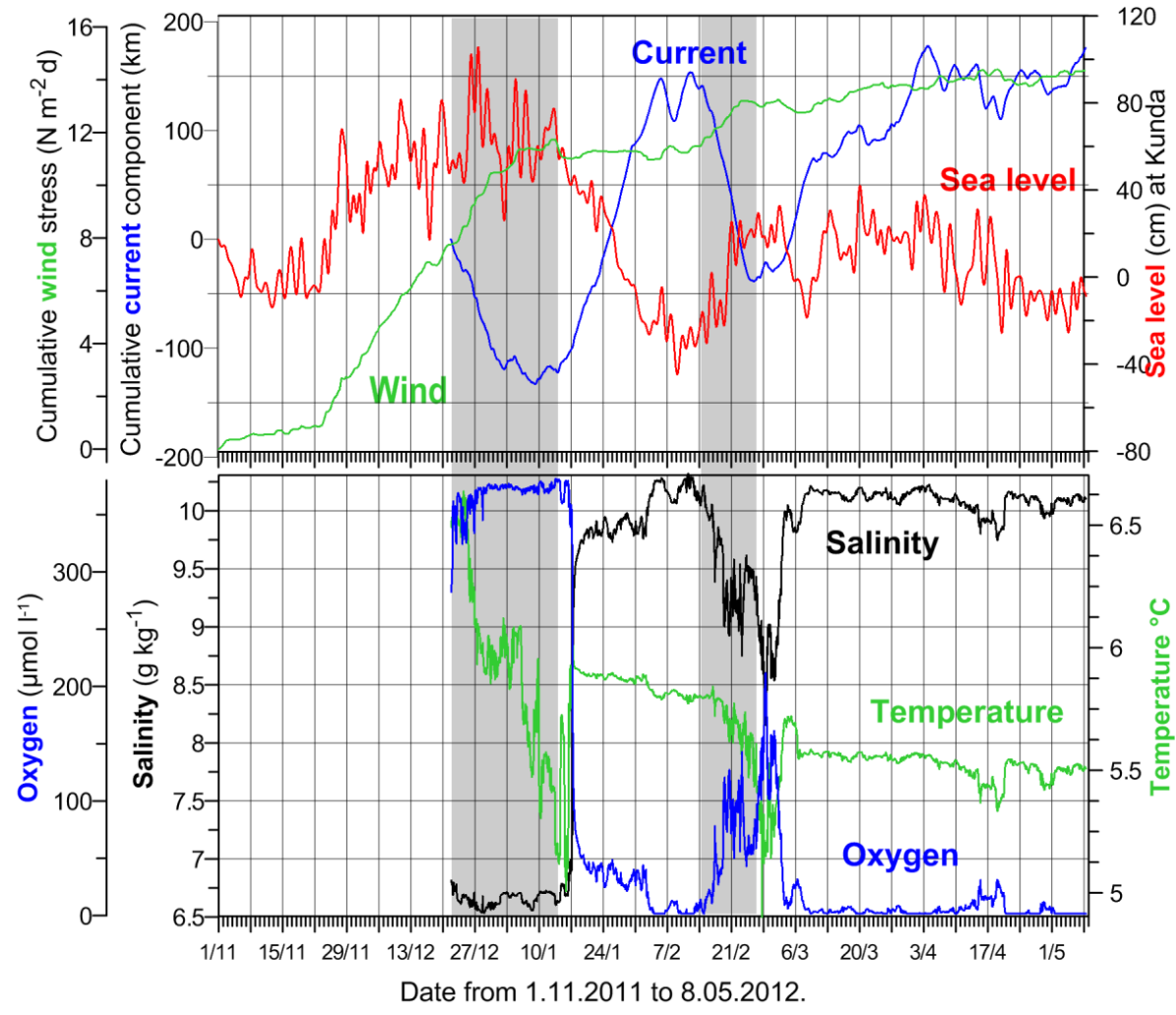

Fig. 6. Cumulative along-gulf axis current velocity component $\left(\mathrm{km}\right.$, blue line), cumulative wind stress $\left(\mathrm{N} \mathrm{m}^{-2} \mathrm{~d}\right.$, green line) and low-pass filtered sea level $(\mathrm{cm})$ time series in the upper panel. Hourly time series of salinity $\left(\mathrm{g} \mathrm{kg}^{-1}\right.$, black line), temperature $\left({ }^{\circ} \mathrm{C}\right.$, green line) and dissolved oxygen $\left(\mu \mathrm{mol} \mathrm{L}{ }^{-1}\right.$, blue line) in the lower panel. Temperature, salinity, dissolved oxygen and current were measured at location A3 from 21 December 2011 to 8 May 2012 at a depth of $85 \mathrm{~m}$ (approximately $5 \mathrm{~m}$ above the seafloor). Wind and sea level measurements were obtained at Tallinnamadal Lighthouse and Kunda coastal station, respectively. Shaded areas mark time intervals when estuarine circulation reversals prevailed.

two-cell circulation in the Gulf: a well-developed reversal event resulted in downwind barotropic flow along the shores and upwind barotropic compensation flow along the thalweg, as is typical in semi-enclosed homogeneous basins (e.g., Sanay and Valle-Levinson, 2005). Further investigation of this theory is warranted.

The shifts in the flow regime of the deep layer were highly dependent on wind forcing. We found the best correlation $\left(r^{2}=0.44, p<0.01, n=3323\right)$ between the low-pass filtered (36 h) NNE wind and an easterly longitudinal inflow current in the deep layer when a time lag of $18 \mathrm{~h}$ was taken into account. This lag is slightly longer than the lag used by Elken et al. (2003), who applied a $15 \mathrm{~h}$ offset in their experimental model. Cumulative wind stress of approximately $1 \mathrm{~N} \mathrm{~m}^{-2} \mathrm{~d}$ was required to start the second reversal event, but weak wind $\left(-0.2 \mathrm{~N} \mathrm{~m}^{-2} \mathrm{~d}\right)$ preceded both estuarine circulation reactivation events. Once estuarine circulation was established, it was well maintained by gravitational forcing without the supporting wind forcing: e.g. the period between two reversal events from mid-January to mid-February (see Fig. 6). Moreover, the estuarine circulation is able to withstand the reversal of favorable winds to a certain extent. Elken et al. (2003) found that the estuarine circulation may be altered if the southwesterly wind component exceeds the mean value by at least 4$5.5 \mathrm{~m} \mathrm{~s}^{-1}$.

The strength of the stratification depended primarily on the presence of the halocline in the deep layer due to the salt wedge intrusion and on the presence of a near-surface halocline in the upper layer due to relatively fresher water in the surface layer. The simultaneous appearance of salty water in the deep layer and fresher riverine water in the surface layer has been observed in a transverse (north-south) section in the summer (Lips et al., 2009). However, in the summer the effect of this phenomenon on the stratification is not as drastic (Liblik and Lips, 2012), because the water column is also thermally stratified. The wind-driven impact on estuarine circulation and respective changes in stratification were also observed in Liverpool Bay (Simpson et al., 1990), in Chesapeake Bay (Scully et al., 2005; Li and Li, 2011) and in the Rio de la Plata estuary (Meccia et al., 2013). In our study, during the reversal events the density difference between the near-bottom and surface water declined below $0.3 \mathrm{~kg} \mathrm{~m}^{-3}$, 
whereas it exceeded $3 \mathrm{~kg} \mathrm{~m}^{-3}$ when estuarine circulation prevailed. Thus, a well-developed reversal event may result in the complete mixing of the water column. The reversal event most likely peaked, and complete mixing occurred between the two cruises on 22 December and 24-25 January. The water column was completely mixed and saturated with oxygen $(98 \%)$ at the two easternmost stations on 24-25 January while the salt wedge was already present at the rest of the stations. To our knowledge, with the exception of the sillseparated Gulf of Bothnia (Håkansson et al., 1996), such a complete mixing event has never been observed in the deep basins of the Baltic Sea.

Based on the wind statistics and analysis of routine CTD measurements in the Gulf of Finland, the winter reversal events occur often and have been occurring with increasingly greater frequency since the 1990s (Elken et al., 2013). However, the approximately 1.5 month-long reversal event observed in December-January was an unusually large event. To evaluate the probability of such a reversal event, we briefly analyzed the NAO index data since 1822 and the autumn-winter Kalbådagrund wind data since 1981. The NAO index of 3.20 in December 2011 clearly exceeded the long-term mean of 0.31 for December. The monthly NAO index in December has exceeded 3.20 only seven times since 1822 , most recently in December 1986. Monthly NAO index values $\geq 3.20$ in January and February have been more common; 15 and 25 such instances were recorded during January and February, respectively, since 1822. The mean monthly NAO index of 1.72 in September-November 2011 was clearly higher than the long-term mean of -0.31 . Only in five years since 1822 has the mean NAO index been higher than 1.72, indicating that airflow from the southwest was exceptionally intense in autumn 2011. The strong relationship between NAO and oxygen conditions has also been detected in the eastern part of the gulf (Eremina et al., 2012). Temperature and salinity profiles developed in the study area (stations A1 and A6, unpublished data) have suggested that the haline stratification was already weakened in September-October. The monthly averages of the wind component from SSW to NNE in Kalbådagrund in November 2011 and January-April 2012 were close to the long-term means (1981-2012) and varied in a range from $-0.3 \mathrm{~m} \mathrm{~s}^{-1}$ to $2.2 \mathrm{~m} \mathrm{~s}^{-1}$. However, December 2011 was extraordinary, when the monthly mean wind component was $7.6 \mathrm{~m} \mathrm{~s}^{-1}$, which exceeds by far the long-term mean of $2.0 \mathrm{~m} \mathrm{~s}^{-1}$ for that month and indicates a clearly dominant SSW wind. Until December 2011, the highest monthly mean SSW wind speed favorable for reversal since 1981 was $6.2 \mathrm{~m} \mathrm{~s}^{-1}$, which was recorded in November of 1982 and 1986.

The oxygen content and salinity were strongly related, as clearly revealed by a coinciding halocline and oxycline. The longitudinal excursions of the salt wedge defined the strength of the vertical stratification and near-bottom oxygen content locally (Fig. 7). During the first reversal event, the stratification was weak and the near-bottom water was well

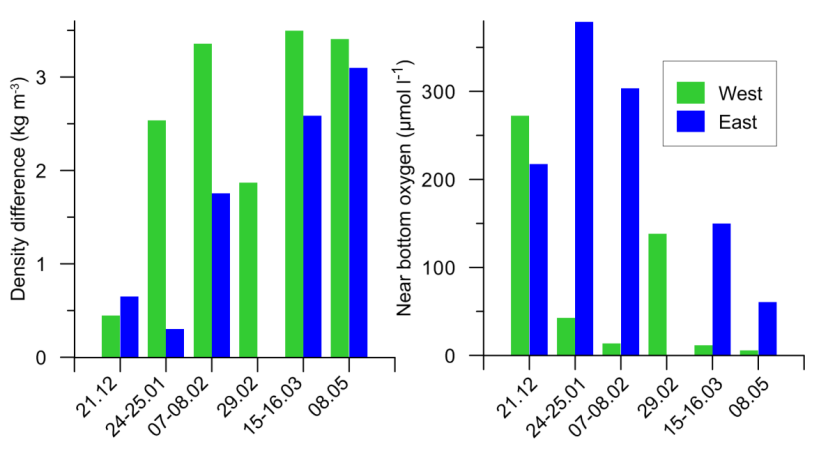

Fig. 7. Average density difference between near-bottom and surface water $\left(\mathrm{kg} \mathrm{m}^{-3}\right.$, left panel) and oxygen concentration in the near-bottom layer $\left(\mu \mathrm{mol} \mathrm{L}^{-1}\right.$, right panel) at westernmost stations A1-A3 (green) and easternmost stations A8-A10 (blue) from 21 December to 8 May. On 29 February, only the western part of the section was visited.

oxygenated $\left(366 \mu \mathrm{mol} \mathrm{L}^{-1}\right.$ or $8.2 \mathrm{mLL}^{-1}$ on average $)$ in the deep layer in the western part of the study area. The same tendency was observed in the case of the relatively weak reversal event observed in February. During periods of estuarine circulation, the stratification increased and the oxygen concentration was clearly under $90 \mu \mathrm{mol} \mathrm{L}^{-1}$. The estimated bottom area covered by hypoxic water was $>1300 \mathrm{~km}^{2}$, and the volume of this water was approximately $12 \mathrm{~km}^{3}$ in midMarch (Table 1, Fig. 8). The near-bottom oxygen concentrations were even lower and the estimated hypoxic area and volume were greater on 8 May. With respect to the crossgulf inclination of the halocline (Lips et al., 2009), our hypoxic area estimations are slightly underestimated rather than overestimated, given the fact that the thalweg of the gulf (our study section) is closer to the southern coast.

The intensification of estuarine circulation often causes improvement in the near-bottom oxygen conditions in estuarine environments due to the import of oxygen-rich ocean waters (e.g., Sato et al., 2012). In this respect, the Gulf of Finland is an unusual marine system, because the imported open sea waters are often depleted of oxygen and the intensification of estuarine circulation leads to an increase in the hypoxic water area and volume. A similar estuarine system is found in the lower St. Lawrence estuary, where the bottom water, isolated from the upper layer by a permanent halocline, has to travel several years before it arrives at the estuary (Gilbert et al., 2005). Because the hypoxic water originates in the intermediate layer of the Baltic Proper, the oxygen conditions there often determine the oxygen conditions in the Gulf of Finland as well. Conley et al. (2002) found that so-called stagnation periods lead to oxygen deficiency in the deep layer of the Baltic Proper, whereas the intermediate layer contains more oxygen during such periods. The long-duration period of stagnation in the 1980s caused a weaker halocline (Liblik and Lips, 2011) and higher deep 

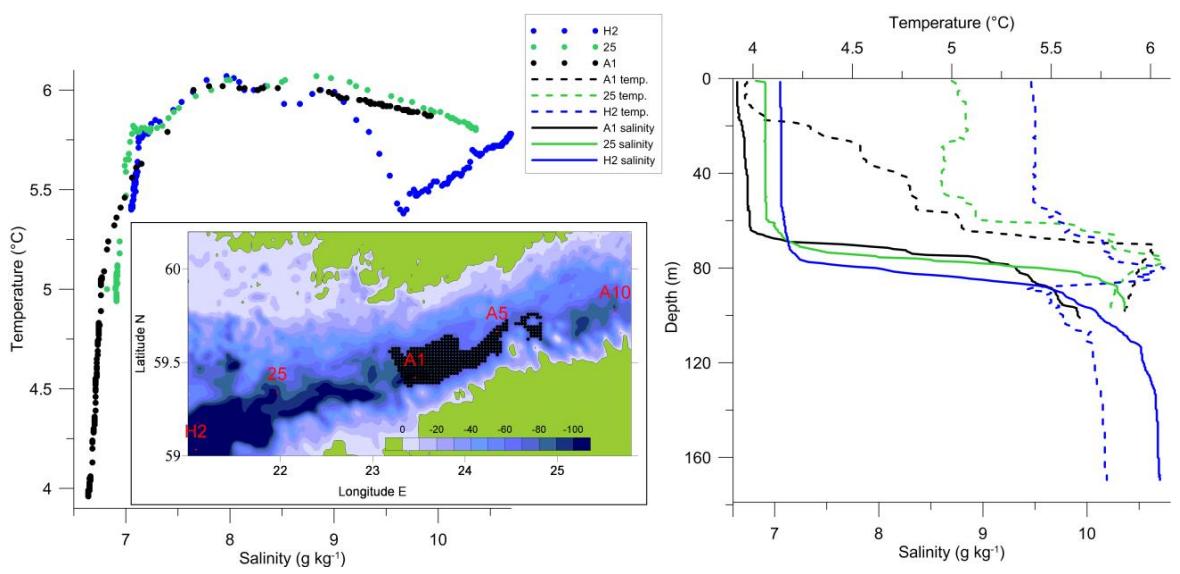

Fig. 8. TS-diagrams (dots on left panel), temperature $\left({ }^{\circ} \mathrm{C}\right.$, dashed lines on right panel) and salinity profiles ( $\mathrm{g} \mathrm{kg}^{-1}$, solid lines on right panel) on 24-25 January and hypoxic area (black area on left panel) on 15-16 March. TS-diagrams and profiles at station H2 (blue), 25 (green) and A1 (black). Hypoxic area was estimated only between the western border of the Gulf of Finland and the easternmost station, A10 (Fig. 1). The bottom topography is drawn from the gridded topography in meters (Seifert et al., 2001).

layer oxygen concentrations (HELCOM, 2009) in the Gulf of Finland, while the oxygen conditions in the deep layer of the Baltic Proper deteriorated during the same period. The inflow from the North Sea therefore has an oxygenation effect opposite to that of the deep layer of the Gulf of Finland and the Baltic Proper.

The reversal events had longer-lasting effects on the oxygen conditions in the deep layer in the eastern part of the study area (Fig. 7). On 15-16 March, two months after the reappearance of the hypoxic salt wedge in the western part of the gulf, the three easternmost stations in the study area were still hypoxic-free. Elken et al. (2013) found that the stratification collapse events occur frequently in the central part of the gulf in the winter. Our results indicate that relatively weak stratification and well-oxygenated water in the central part of the gulf may occur simultaneously with a hypoxic salt wedge in the deep layer in the western part of the gulf (Fig. 7). This pattern may be related to the topography of the gulf: a slight (up to $10 \mathrm{~m}$ ) bottom rise located in the area around station A7 (Fig. 1). This slightly shallower section of the thalweg impeded the eastward spread of the salt wedge. However, if the thickness of the salt wedge was sufficient, as on 8 May, then it penetrated farther to the east and occupied the bottom layer along the entire thalweg. Furthermore, the eastward advection of the salt wedge can lead to hypoxic conditions even in the eastern part of the gulf (i.e., the Russian waters of the gulf between Kotlin and the Hogland Islands) (Eremina et al., 2012).

During the cruise of 24-25 January, we also acquired CTD profiles at two stations in the northern Baltic Proper: estonian National Monitoring Station 25, at a depth of $100 \mathrm{~m}$, and the international $170 \mathrm{~m}$-deep monitoring station $\mathrm{H} 2$ (Fig. 8). The hypoxic saltwater wedge at station 25 was approximately $20 \mathrm{~m}$ thick and was situated in a depth range from $80 \mathrm{~m}$ to the bottom. The hypoxic water there seemed to be a mixture of two waters: saltier and slightly colder water originating from the area of station $\mathrm{H} 2$ at a depth range of 110 $115 \mathrm{~m}$ and warmer water from the upper part of the halocline. The hypoxic deep layer found at westernmost station A1 was a mixture of salty near-bottom water from station 25 and fresher, warmer water. This fresher, warmer water evidently also originated outside the Gulf of Finland, as the water column temperature was below $6{ }^{\circ} \mathrm{C}$ in the gulf at that time. Thus, the deep water salt wedge observed in the study area on 24-25 January after a major reversal event originated in the northern Baltic Proper at a depth range of 110 $115 \mathrm{~m}$. This depth most likely was deeper than normal due to the seasonal weakening and descent of the halocline in the northern Baltic Proper (Matthäus, 1984). In addition, Elken et al. (2006) found that the counter-estuarine transport in the Gulf of Finland reduces the vertical stability and decreases the halocline in the NE Baltic Proper.

The current structure in the deep layer during development of the second reversal event (Fig. 4) indicated that the weakening of the halocline and oxygenation of the bottom water were most likely related to the horizontal advection. For confirmation, we plotted salinity-oxygen diagrams and profiles before the reversal event (7-8 February) and during the reversal event (29 February) at station A3 (Fig. 9). Based on the consecutive salinity and oxygen profiles, the saltier and hypoxic water disappeared from the deep layer at A3 station by 29 February, whereas an increase in the salinity and decrease in oxygen were not observed in the layer above (10$70 \mathrm{~m}$ ). Thus, pure vertical mixing could not have caused this disappearance. This fresher, oxygenated bottom water originated from the eastern part of the thalweg: the deep layer water at station A3 on 29 February had an oxygen content and salinity similar to that of the deep layer water observed 


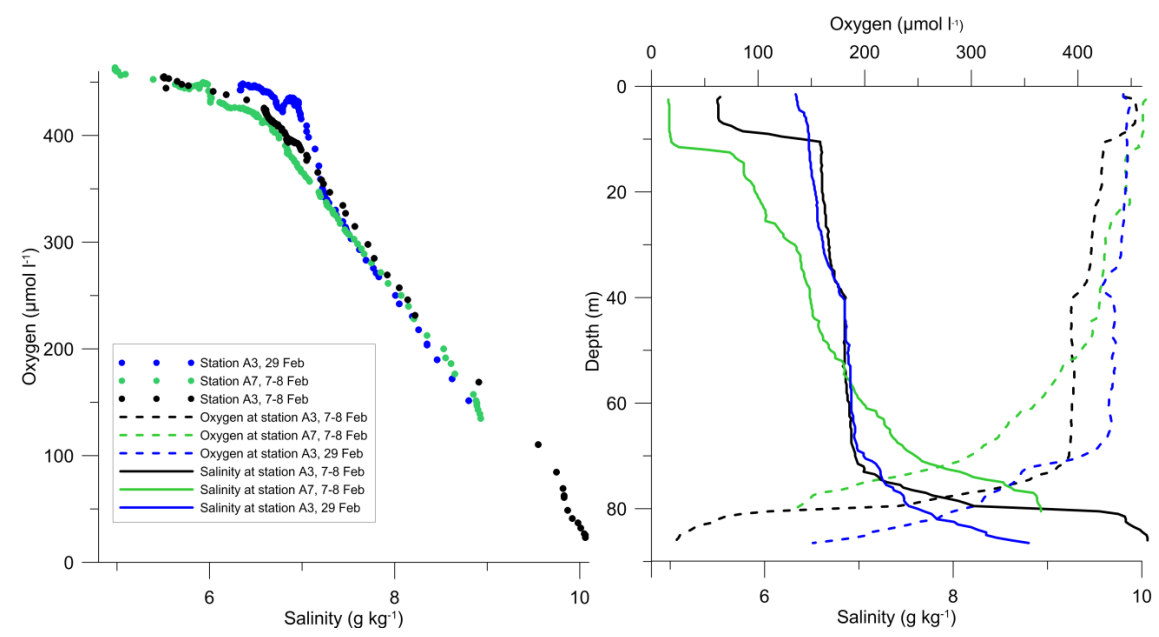

Fig. 9. Salinity-oxygen diagrams (dots on left panel) and salinity $\left(\mathrm{g} \mathrm{kg}^{-1}\right.$, solid lines on right panel) and dissolved oxygen $\left(\mu \mathrm{mol} \mathrm{L}^{-1}\right.$, dashed lines on right panel) profiles on 7-8 February (black) and 29 February (blue) at station A3 and on 7-8 February (green) at station A7.

at A7 station on 7-8 February (see oxygen-salinity plot in Fig. 9). An opposite change in the salinity occurred simultaneously in the upper $10 \mathrm{~m}$ layer, but most likely a minor amount of vertical mixing was also involved, as the $10-30 \mathrm{~m}$ layer had become fresher. Similar changes in the upper layer salinity were observed in the summer when the southwesterly winds were dominant (Liblik and Lips, 2012). Therefore, the halocline disappearance and oxygenation of the bottom water may be related to the advection of oxygen-rich water from the eastern part of the study area. However, when eastward transport of relatively salty water in the upper layer and westward transport of relatively fresher water in the deep layer last long enough, complete mixing of the water column may occur. The homogenous water column observed at the two easternmost stations on 24-25 January most likely was the consequence of such an event.

The effects related to oxygen depletion clearly impact the biogeochemical cycles in the Baltic Sea (HELCOM, 2009). At the same time as our cruise of 24-25 January, the Estonian national monitoring survey was conducted, and nearbottom water samples were collected for nutrient analysis near the thalweg. The nutrient concentrations clearly differed between the hypoxic and well-oxygenated deep layer waters. The concentrations of $\mathrm{NH}_{4}, \mathrm{NO}_{2}+\mathrm{NO}_{3}$ and $\mathrm{PO}_{4}$ in water affected by the hypoxic salt wedge were in the range of 4.2-6.4, 0.1-2.3 and 2.7-4.0 $\mu \mathrm{mol} \mathrm{L}^{-1}$, respectively, while the concentrations in the well-oxygenated near-bottom water were in the range of $0.1-0.2,6.8-8.1$ and $0.9-1.0 \mu \mathrm{mol} \mathrm{L}^{-1}$, respectively. These findings confirm earlier conclusions that hypoxic conditions in the near-bottom layer cause the release of phosphorus from the sediment (e.g., Viktorsson et al., 2012), the interruption of the nitrification-denitrification chain and enrichment in ammonium (e.g., Jäntti et al., 2012) in the Gulf of Finland. In these respects, the reversal events affect the nutrient pool in the Gulf of Finland in three ways:
(1) interrupting estuarine transport of phosphate-rich waters from the Baltic Proper (Lips et al., 2008), (2) allowing more efficient diapycnal mixing (Elken et al., 2003) and nutrient transport to the euphotic zone due to weaker stratification (Reissmann et al., 2009), and (3) altering the benthic nutrient dynamics in the gulf (Hietanen and Lukkari, 2007). Thus, the reversal events potentially have an effect on the entire ecosystem of the gulf.

\section{Conclusions}

The winter temporary reversals of the standard estuarine circulation clearly influence the stratification and oxygen conditions in the Gulf of Finland. As a result of two circulation reversals in winter 2011-2012, the stratification was greatly weakened, the current structure was altered and the hypoxic salt wedge disappeared during the reversal events. The welldeveloped reversal event (December-January) lasted approximately 1.5 months and caused the complete disappearance of stratification, barotropic flow along the thalweg and nearly homogenous oxygen concentrations throughout the water column. The shifts from estuarine circulation to reversed circulation and vice versa were both associated with strong currents (up to $40 \mathrm{~cm} \mathrm{~s}^{-1}$ ) in the deep layer. The vertical stratification and oxygen conditions in the deep layer were defined by longitudinal east- and westward migrations of the salt wedge. The hypoxic salt wedge originated from the NE Baltic Proper at a depth range of $110-115 \mathrm{~m}$. Thus, the deterioration of the deep layer oxygen conditions was solely related to the advective transport of hypoxic water from the NE Baltic Proper. Likewise, the weakening of the halocline and oxygenation of the near-bottom water was most likely related to westward advection along the thalweg. However, long-duration counter-advective transport in the upper and 
deep layer most likely caused convection and complete mixing of the entire water column.

The change from oxygenated to hypoxic conditions at the entrance to the gulf occurred very rapidly (within $12 \mathrm{~h}$ ).

The near-bottom layer of the gulf was nearly hypoxic-free even in instances of relatively weak reversal during February. However, during estuarine circulation periods the estimated bottom area covered by hypoxic water was $>1300 \mathrm{~km}^{2}$. Reversal events had longer-lasting effects on the near-bottom oxygen conditions in the eastern part of the study area, where hypoxic-free conditions remained two months after the reappearance of the hypoxic salt wedge in the western part of the Gulf. These conditions most likely were related to the topography of the Gulf: the shallower area between Tallinn and Helsinki along the thalweg may have prevented the salt wedge from spreading farther east. However, if estuarine circulation prevailed long enough, then the salt wedge was able to penetrate farther east and occupy the bottom layer along the entire thalweg.

Acknowledgements. This study was supported by the Estonian Science Foundation (grant Nos. 9278 and 9382) and the EstKliima project, funded by Environmental Protection and Technology Programme No. 3.2.0802.11-0043 of the European Regional Fund. The Finnish Meteorological Institute kindly provided Kalbådagrund wind data, and the Estonian Meteorological and Hydrological Institute the sea level data. We are thankful to A. Trei and F. Buschmann for performing oxygen measurements, T. Kõuts for providing Tallinnamadal wind data and S. Stjopin for providing nutrient data. Likewise, we thank the crew of R/V Salme. We thank Urmas Lips for his comments on the methodology. We would like to thank the two reviewers and the editor for their valuable comments.

Edited by: M. Hoppema

\section{References}

Alenius, P., Myrberg, K., and Nekrasov A.: The physical oceanography of the Gulf of Finland: a review, Boreal Environ. Res., 3, 97-125, 1998.

Alenius, P., Nekrasov, A., and Myrberg K.: Variability of the baroclinic Rossby radius in the Gulf of Finland, Cont. Shelf Res., 23, 563-573, 2003.

Almroth, E., Tengberg, A., Andersson, J. H., Pakhomova, S., and Hall P. O. J.: Effects of resuspension on benthic fluxes of oxygen, nutrients, dissolved inorganic carbon, iron and manganese in the Gulf of Finland, Baltic Sea, Cont. Shelf Res., 29, 807-818, 2009.

Bergström, S. and Carlsson, B.: River runoff to the Baltic Sea: 1950-1990, Ambio, 23, 280-287, 1994.

Butterworth, S.: On the theory of filter amplifiers, Experimental Wireless and the Wireless Engineer, 7, 536-541, 1930.

Conley, D. J., Humborg, C., Rahm, L., Savchuk, O. P., and Wulff, F.: Hypoxia in the Baltic Sea and basin-scale changes in phosphorus biogeochemistry, Enviro. Sci. Technol., 36, 5315-5320, 2002.
Conley, D. J.; Björck, S.; Bonsdorff, E.; Carstensen, J.; Destouni, G.; Gustafsson, B. G.; Hietanen, S.; Kortekaas, M.; Kuosa, H.; Meier, H. E. M.; Müller-Karulis, B.; Nordberg, K.; Norkko, A.; Nürnberg, G.; Pitkänen, H.; Rabalais, N. N.; Rosenberg, R.; Savchuk, O. P.; Slomp, C. P.; Voss, M.; Wulff, F.; Zillén, L.: Hypoxia-related processes in the Baltic Sea, Environ. Sci. Technol., 43, 3412-3420, 2009.

Diaz, R. J. and Rosenberg, R.: Spreading Dead Zones and Consequences for Marine Ecosystems, Science, 321, 926-929, doi:10.1126/science.1156401, 2008.

Elken, J., Raudsepp, U., and Lips, U.: On the estuarine transport reversal in deep layers of the Gulf of Finland, J. Sea Res., 49, 267-274, 2003.

Elken, J., Mälkki, P., Alenius, P., and Stipa, T.: Large halocline variations in the Northern Baltic Proper and associated meso - and basin-scale processes, Oceanologia, 48, 91-117, 2006.

Elken, J., Raudsepp, U., Laanemets, J., Passenko, J., Maljutenko, I., Pärn, O., and Keevallik, S.: Increased frequency of wintertime stratification collapse events in the Gulf of Finland since the 1990s, J. Marine Syst., doi:10.1016/j.jmarsys.2013.04.015, 2013.

Eremina, T. R., Maximov, A. A., and Voloshchuk, E. V.: The influence of climate's variability on the deep-water oxygen conditions in the east of the Gulf of Finland, Oceanology, 52, 771-779, 2012.

Feistel, R., Nausch, G., Matthäus, W., and Hagen, E.: Temporal and Spatial Evolution of the Baltic Deep Water Renewal in Spring 2003, Oceanologia, 45, 623-642, 2003.

Fofonoff, N. P. and Millard, Jr., R. C.: Algorithms for computation of fundamental properties of seawater, Unesco Tech. Pap. Mar. Sci., 44, 1-58, 1983.

Fonselius, S. and Valderrama, J.: One hundred years of hydrographic measurements in the Baltic Sea, J. Sea Res., 49, 229241, 2003.

Gilbert, D., Sundby, B., Gobeil, C., Mucci, A., and Tremblay, G. H.: A seventy-two-year record of diminishing deep-water oxygen in the St. Lawrence estuary: the northwest Atlantic connection, Limnol. Oceanogr., 50, 1654-1666, 2005.

Haapala, J. and Alenius, P.: Temperature and salinity statistics for the northern Baltic Sea 1961-1990, Finnish Mar. Res., 262, 51121,1994

Håkansson, B., Alenius, P., and Brydsten, L.: Physical environment in the Gulf of Bothnia, Ambio Spec. Rep., 8, 5-12, 1996.

Hansen, D. V. and Rattray, M.: New dimensions in estuary classification, Limnol. Oceanogr., 11, 319-326, 1966.

HELCOM (Helsinki Commission): Eutrophication in the Baltic Sea: an integrated thematic assessment of the effects of nutrient enrichment in the Baltic Sea region, Baltic Sea Environment Proceedings, 115, 2009.

Hietanen, S. and Lukkari, K.: Effects of short-term anoxia on benthic denitrification, nutrient fluxes and phosphorus forms in coastal Baltic sediment, Aquat. Microb. Ecol., 49, 293-302, doi:10.3354/ame01146, 2007.

Jäntti, H. and Hietanen, H.: The Effects of Hypoxia on Sediment Nitrogen Cycling in the Baltic Sea, AMBIO, 41, 161-169, doi:10.1007/s13280-011-0233-6, 2012.

Jones, P. D., Jonsson, T., and Wheeler, D.: Extension to the North Atlantic Oscillation using early instrumental pressure observa- 
tions from Gibraltar and South-West Iceland, Int. J. Climatol., 17, 1433-1450, 1997.

Keevallik, S. and Soomere, T.: Towards quantifying variations in wind parameters across the Gulf of Finland, Est. J. Earth Sci., 59, 288-297, 2010.

Kullenberg, G.: Physical oceanography, in: The Baltic Sea, Elsevier Publishing Company, Amsterdam, 135-182, 1981

Lagemaa, P., Suhhova, I., Nõmm, M., Pavelson, J., and Elken, J.: Comparison of current simulations by the state-of-the-art operational models in the Gulf of Finland, in: IEEE Conference Proceedings, IEEE/OES Baltic 2010 International Symposium, 2527 August 2010, Riga, Latvia, 1-11, 2010.

Laine, A. O., Andersin, A.-B., Leiniö, S., and Zuur, A. F.: Stratification-induced hypoxia as a structuring factor of macrozoobenthos in the open Gulf of Finland (Baltic Sea), J. Sea Res., 57, 65-77, 2007.

Launiainen, J. and Saarinen, J.: Marine wind characteristics in the northern Baltic Sea, Finnish, Mar. Res., 250, 52-86, 1984.

Li, Y. and Li, M.: Effects of wind on stratification and circulation in a partially mixed estuary, J. Geophys. Res., 116, C12012, doi:10.1029/2010JC006893, 2011.

Liblik, T. and Lips, U.: Characteristics and variability of the vertical thermohaline structure in the Gulf of Finland in summer, Boreal Environ. Res., 16, 73-83, 2011.

Liblik, T. and Lips, U.: Variability of synoptic-scale quasistationary thermohaline stratification patterns in the Gulf of Finland in summer 2009, Ocean Sci., 8, 603-614, doi:10.5194/os-8603-2012, 2012.

Lips, I., Lips, U., and Liblik, T.: Consequences of coastal upwelling events on physical and chemical patterns in the central Gulf of Finland (Baltic Sea), Cont. Shelf Res., 29, 1836-1847, 2009.

Lips, U., Lips, I., Liblik, T., and Elken, J.: Estuarine transport versus vertical movement and mixing of water masses in the Gulf of Finland (Baltic Sea), in: IEEE Conference Proceedings, US/EU-Baltic Symposium "Ocean Observations, EcosystemBased Management \& Forecasting”, Tallinn, 27-29 May, 2008, IEEE, 2008, (IEEE Conference Proceedings), 1-8, 2008.

MacCready, P. and Geyer., W. R.: Advances in estuarine physics, Annual Reviews of Marine Science, 2, 35-58, 2010.

Matthäus, W.: Climatic and seasonal variability of oceanological parameters in the Baltic Sea, Beiträge zur Meereskunde, 51, 2949, 1984.

Matthäus, W. and Lass, H. U.: The recent salt inflow into the Baltic Sea, J. Phys. Oceanogr., 25, 280-286, 1995.

Meccia, V. L., Simionato, C. G., and Guerrero, R. A.: The Rio de la Plata estuary response to wind variability in synoptic timescale: salinity fields and salt wedge structure, J. Coastal Res., 29, 6177, 2013.
Millero, F. J., Feistel, R., Wright, D. G., and McDoughall, T. J.: The composition of Standard Seawater and the definition of the Reference-Composition Salinity Scale, Deep-Sea Res. Pt. I, 55, 50-72, doi:10.1016/j.dsr.2007.10.001, 2008.

Reissmann, J. H., Burchard, H., Feistel, R., Hagen, E., Lass, H. U., Mohrholz, V., Nausch, G., Umlauf, L., and Wieczorek, G.: Vertical mixing in the Baltic Sea and consequences for eutrophication - A review, Prog. Oceanogr., 82, 47-80, 2009.

Sanay, R. and Valle-Levinson, A.: Wind-induced circulation in semienclosed homogeneous, rotating basins, J. Phys. Oceanogr., 35, 2520-2531, 2005.

Sato, C., Nakayama, K. and Furukawa, K.: Contributions of wind and river effects on DO concentration in Tokyo Bay, Est. Coast. Shelf Sci., 109, 91-97, 2012.

Savchuk, O. P.: Large-scale dynamics of hypoxia in the Baltic Sea, in: Chemical Structure of Pelagic Redox Interfaces: Observation and Modelling, Hdb., Springer Verlag, Berlin Heidelberg, Germany, Env. Chem., 22, 137-160, 2010.

Scully, M. E., Friedrichs, C., and Brubaker, J.: Control of estuarine stratification and mixing by wind-induced straining of the estuarine density field, Estuaries, 28, 321-326, 2005.

Seifert, T., Tauber, F., and Kayser, B.: A high resolution spherical grid topography of the Baltic Sea - 2nd edition, Baltic Sea Science Congress, Stockholm 25-29 November 2001, Poster \#147, www.io-warnemuende.de/iowtopo, 2001.

Simpson, J. H., Brown, J., Matthews, J., and Allen, G.: Tidal straining, density currents, and stirring in the control of estuarine stratification, Estuaries, 13, 125-132, 1990.

Vahtera, E., Conley, D. J., Gustafsson, B. G., Kuosa, H., Pitkänen, H., Savchuk, O. P., Tamminen, T., Viitasalo, M., Voss, M., Wasmund, N., and Wulf, F.: Internal ecosystem feedbacks enhance nitrogen-fixing cyanobacteria blooms and complicate management in the Baltic Sea, Ambio, 36, 186-194, 2007.

Viktorsson, L., Almroth-Rosell, E., Tengberg, A., Vankevich, R., Neelov, I., Isaev, R., Kravtsov, V., and Hall, P. O. J.: Benthic Phosphorus Dynamics in the Gulf of Finland, Aquat. Geochem., 18, 543-564, doi:10.1007/s10498-011-9155-y, 2012.

Whitney, M. M. and Codiga, D.: Response of a large stratified estuary to wind events: observations, simulations, and theory for Long Island Sound, J. Phys. Oceanogr., 41, 1308-1327, 2011.

Zillén, L., Conley, D. J., Andrén, T., Andrén, E., and Björck, S.: Past occurrences of hypoxia in the Baltic Sea and the role of climate variability, environmental change and human impact, Earth-Sci. Rev., 91, 77-92, 2008. 